\title{
Correction to: Sexual and reproductive health (SRH): a key issue in the emergency response to the coronavirus disease (COVID- 19) outbreak
}

Kun Tang ${ }^{1 *}$, Junjian Gaoshan ${ }^{2}$, Babatunde Ahonsi ${ }^{2}$, Moazzam Ali ${ }^{3}$, Mercedes Bonet ${ }^{3}$, Nathalie Broutet ${ }^{3}$, Edna Kara ${ }^{3}$, Caron Kim ${ }^{3}$, Anna Thorson ${ }^{3}$ and Soe Soe Thwin ${ }^{3}$

Correction to: Reprod Health (2020) 17:59

https://doi.org/10.1186/s12978-020-0900-9

Following publication of the original article [1], we have been notified that there is a mistake in the authors' team as some authors were not added.

The following authors have to be added:

Moazzam Ali

Mercedes Bonet

Nathalie Broutet

Edna Kara

Caron Kim

Anna Thorson

Soe Soe Thwin

Affiliation of the above-mentioned authors is:

UNDP/UNFPA/UNICEF/WHO/World Bank Special Programme of Research, Development and Research Training in Human Reproduction (HRP), Geneva, Switzerland

\section{Author details}

'School of Medicine, Tsinghua University, Beijing, China. ${ }^{2}$ United Nations Population Fund China Office, Beijing, China. ${ }^{3}$ UNDP/UNFPA/UNICEF/WHO/ World Bank Special Programme of Research, Development and Research Training in Human Reproduction (HRP), Geneva, Switzerland.
Published online: 26 May 2020

\section{Reference}

1. Tang, et al. Sexual and reproductive health (SRH): a key issue in the emergency response to the coronavirus disease (COVID- 19) outbreak. Reprod Health. 2020;17:59. https://doi.org/10.1186/s12978-020-0900-9.

The original article can be found online at https://doi.org/10.1186/s12978020-0900-9.

* Correspondence: tangk@mail.tsinghua.edu.cn

${ }^{1}$ School of Medicine, Tsinghua University, Beijing, China

Full list of author information is available at the end of the article

(c) The Author(s). 2020 Open Access This article is licensed under a Creative Commons Attribution 4.0 International License, which permits use, sharing, adaptation, distribution and reproduction in any medium or format, as long as you give appropriate credit to the original author(s) and the source, provide a link to the Creative Commons licence, and indicate if changes were made. The images or other third party material in this article are included in the article's Creative Commons licence, unless indicated otherwise in a credit line to the material. If material is not included in the article's Creative Commons licence and your intended use is not permitted by statutory regulation or exceeds the permitted use, you will need to obtain permission directly from the copyright holder. To view a copy of this licence, visit http://creativecommons.org/licenses/by/4.0/ The Creative Commons Public Domain Dedication waiver (http://creativecommons.org/publicdomain/zero/1.0/) applies to the data made available in this article, unless otherwise stated in a credit line to the data. 